\title{
A study of the high-frequency hearing thresholds of dentistry professionals
}

\section{Estudo dos limiares de audibilidade nas altas frequências em trabalhadores da área odontológica}

\author{
Andréa Cintra Lopes ${ }^{1}$, Ana Dolores Passarelli de Melo², Cibele Carmelo Santos ${ }^{3}$. \\ 1) Doctor. Professor Doctor. \\ 2) Master of Human Communication Science by Faculty of Odontology of USP - Bauru, São Paulo. Speech Therapy Clinics of Spazio Fonoaudiológico, Lima - Peru. \\ 3) Master of Human Communication Science by Faculty of Odontology of USP - Bauru, São Paulo. Speech Therapist of AMA - Hearing Aids and CPAP. \\ Institution: Faculty of Odontology of Bauru - University de São Paulo \\ Bauru / SP - Brazil. \\ Mailing address: Andréa Cintra Lopes - Alameda Dr. Octávio Pinheiro Brizolla, 9-75 - Departamento de Fonoaudiologia - Vila Universitária - Bauru / SP - Brazil - Zip- \\ code: 17012-901 - E-mail: aclopes@usp.br \\ Financial sponsorship: FAPESP, process n. 2007/01074-7. \\ Article received in September 30, 2011. Article Approved in October 26, 2011.
}

\section{SUMMARY}

Introduction: In the dentistry practice, dentists are exposed to harmful effects caused by several factors, such as the noise produced by their work instruments. In 1959, the American Dental Association recommended periodical hearing assessments and the use of ear protectors. Aquiring more information regarding dentists', dental nurses', and prosthodontists' hearing abilities is necessary to propose prevention measures and early treatment strategies.

Objective: To investigate the auditory thresholds of dentists, dental nurses, and prosthodontists.

Method: In this clinical and experimental study, 44 dentists (Group I; GI), 36 dental nurses (Group II; GII), and 28 prosthodontists (Group III; GIII) were included, , with a total of 108 professionals. The procedures that were performed included a specific interview, ear canal inspection, conventional and high-frequency threshold audiometry, a speech reception threshold test, and an acoustic impedance test.

Results: In the 3 groups that were tested, the comparison between the mean hearing thresholds provided evidence of worsened hearing ability relative to the increase in frequency. For the tritonal mean at 500 to $2,000 \mathrm{~Hz}$ and 3,000 to $6,000 \mathrm{~Hz}$, GIII presented the worst thresholds. For the mean of the high frequencies $(9,000$ and 16,000 Hz), GII presented the worst thresholds.

Conclusion: The conventional hearing threshold evaluation did not demonstrate alterations in the 3 groups that were tested; however, the complementary tests such as high-frequency audiometry provided greater efficacy in the early detection of hearing problems, since this population's hearing loss impaired hearing ability at frequencies that are not tested by the conventional tests. Therefore, we emphasize the need of utilizing high-frequency threshold audiometry in the hearing assessment routine in combination with other audiological tests. Keywords: audiometry, hearing loss, high-frequency, hearing loss, noise-induced, dentistry.

\section{RESUMO}

Introdução: Na prática odontológica, o Cirurgião-Dentista está sujeito aos efeitos nocivos provocados por diversos agentes, como pelo ruído emitido por seus instrumentos de trabalho. Em 1959, a American Dental Association recomendava avaliações audiométricas periódicas e uso de proteção auditiva. São necessárias maiores informações sobre o comportamento auditivo dessa população: Cirurgiões-Dentistas, Auxiliares e Protéticos para se propor medidas de prevenção e tratamento precoce.

Objetivo: Investigar os limiares de audibilidade em Cirurgiões-Dentistas, Auxiliares e Protéticos.

Método: Forma de estudo: Estudo Clínico.Participaram 108 profissionais, sendo 44 Cirurgiões-Dentistas (GI), 36 Auxiliares (G II) e 28 Protéticos (GIII). Foram realizadas: entrevista específica, meatoscopia, audiometria tonal convencional e de altas frequências, logoaudiometria, imitanciometria.

Resultados: A comparação entre as médias dos limiares evidenciaram piora com o aumento da frequência para os 3 grupos testados; para a média tritonal de 500 a $2000 \mathrm{~Hz}$, e 3000 a 6000 $\mathrm{Hz}$, o GIII apresentou os piores limiares, já para a média das altas frequências $(9000 \mathrm{a} 16.000 \mathrm{~Hz})$ o GII apresentou os piores limiares.

Conclusão: A avaliação audiológica convencional não identificou exames alterados para os três grupos testados, no entanto, o exame da avaliação audiológica complementar como a audiometria de altas frequências indicou maior sensibilidade na detecção precoce de alterações auditivas uma vez que a perda auditiva dessa população acomete as frequências que não são testadas nos exames convencionais. Dessa maneira enfatizamos nesse trabalho a necessidade de inserir na rotina de exames a audiometria de altas frequências juntamente com os outros exames audiológicos.

Palavras-chave: audiometria, perda auditiva de alta frequência, ruído, odontologia geral. 


\section{INTRODUCTION}

Noise is one of the most harmful agents for health, primarily for hearing, and it is often unavoidable at workplaces and entertainment venues. Noise-induced hearing loss (NIHL), which is hearing loss that is induced by high levels of sound pressure, is one of the most common occupational diseases.

Currently, noise is a constant part of people's daily activities, as it is present in traffic, leisure, and work; therefore, NIHL may become one of the main chronic diseases in the future (FIORINI, 2000).

NIHL is defined as sensorineural hearing loss that occurs due to systematic occupational exposure to high levels of sound pressure, thus causing damage to the hair cells of the organ of Corti. Generally, this hearing loss is bilateral and symmetrical, insidious and irreversible, and is directly related to the period of exposure and individual susceptibility (Brazilian National Noise and Hearing Preservation Committee, 1999; Rabinowitz, 2000). This hearing disturbance is initially manifested at the frequencies of 6,000 $\mathrm{Hz}, 4,000 \mathrm{~Hz}$, and 3,000 $\mathrm{Hz}$, and broadens progressively to the frequencies of $8,000 \mathrm{~Hz}, 2,000 \mathrm{~Hz}$, $1,000 \mathrm{~Hz}, 500 \mathrm{~Hz}$, and $250 \mathrm{~Hz}$. Noise rarely leads to profound hearing loss, which generally does not exceed 75 $\mathrm{dB}$ for high frequencies and $40 \mathrm{~dB}$ for low frequencies, and reaching its upper limit in the first 10 to 15 years of exposure (Luxon, 1998; Hanger, Barbosa-Branco, 2004; GatTo et al., 2005).

Generally, professionals only notice a hearing difficulty when the lesion is at an advanced stage, as the hearing symptoms are insidious and manifest late ( $\mathrm{S}_{\mathrm{AVA}}$, 2005). Continuous exposure to high levels of sounds may not only result in hearing damage, but also in a few secondary alterations, such as tinnitus, stress, physiological alterations to the heart rhythm and to blood pressure, as well as difficulty in discriminating speech sounds, especially in noisy environments. Noise causes physical exhaustion, chemical, metabolic, and mechanic disturbances to the sensory hearing organ, thus resulting in partial or total hearing loss of the organ of Corti, which is located in the internal part of the ear. (OtONI A, BOger ME, Barbosa-Branco A, Shimizu He, Maftum MA, 2008).

Dentists are typically exposed to 2 types of noise: external noise from the work environment and noise from their own work equipment, such as the noise from high and low rotation motors, compressors, air conditioners, amalgamators, aspirators, and others (Hinze, Deleon, and Mitchel, 1999). In addition to noise, they are exposed to other factors, including chemicals (manipulated substances, especially mercury), biological agents (the oral cavity is full of microorganisms and the risk of contracting diseases such as hepatitis and aquired immune deficiency syndrome (AIDS) is high), mechanical agents (body lesions caused by to the instruments that are used), social stresses (having occupation that involves tension and requires mastery of the situation to facilitate the patient/professional relationship), and ergonomic challenges (due to the body position while working, the professional is subjected to back and arm problems and varicose veins) (SouZA, 1997). According to PRESTA et al. (2004) Dentists have frequently presented with discomforts that are related to the nature of their profession, which may progress to repetitive strain injuries or work-related musculoskeletal disorders.

In 1959, the American Dental Association (ADA) had already recommended periodic hearing assessments for dentists, due to their prolonged exposure to highfrequency sounds, which were caused by instruments like high speed drills, ejection systems, ultrasound equipment, model clippers, and instruments with high suction and vibration speeds, which can lead to hearing loss. Studies (Altinoz et al., 2001; Fernandes et al., 2004) that measured the noise levels in dental practices observed noise levels that were higher than $80 \mathrm{~dB}$ Sound Pressure Level (SPL).

In Brazil, Law number 6.514 of the Brazilian Labor Code (Cousolidação da Leis do trabalho; CLT), relates the parameters that provide acoustic comfort for practitioners with the norms of the Brazilian Association of Technical Norms (ABNT). The Brazilian employment legislation considers the maximum tolerable level of noise to be $85 \mathrm{~dB}$ SPL in an 8-hour shift (Segurança e Medicina do Trabalho, 1991); The Brazilian Standard (NBR) 10.152 indicates that this level should be between 35 and $45 \mathrm{~dB}$ (A) for a dental office.

Paraguay (1999) verified that dentists with 5 or more years of practice presented hearing disturbances by tonal threshold audiometry.

LEGGAT (2000) stated that the reason that more experienced dentists suffer from hearing alterations may be due to previous exposure to older equipment. However, this possibility was not considered in this study, as the study population was relatively young.

Previous studies (OliveIra et al., 2007; TORRÊs et al., 2007; Melo et al., 2008) have shown that dental professionals should be aware of occupational noise, as well as of the harmful consequences that it can have on their health. This understanding should begin early, during the undergraduate course, when the professionals are being educated, so that, aware of the risks that they may be exposed to, they will 
be able to prevent them, instead of attempting to lessen or treat the problems caused by them.

In Brazil, the prevention of occupational diseases and occupational accidents began with the CLT in 1943, and ever since, the attention to hearing in noisy work environments has intensified. With the promulgation of Ordinance number 3.214/78 there was an important improvement in the scope of hearing conservation efforts, by means of the Control Program Occupational Health Medical-PCMSO (NR-7), which made the tonal threshold audiometry mandatory.

The interest in early diagnosis has increased, and considering the progress of the technology that is aimed at the diagnosis of hearing loss, as well as the prevalence of hearing alterations even in the absence of complaints, which are commonly found by tonal threshold audiometry, other methods have been used to identify hearing alterations at an early stage.

According to previous studies, high-frequency (between 9,000 and 18,000 Hz) tonal audiometry is an instrument that is effective for the early diagnosis of hearing problems due to exposure to noise (PORTO et al., 2004; Lopes and Godoy, 2006; Amorin, et al., 2008). Studies such as those conducted by Мота (2002) and Porto et al. (2004) that investigated hearing at conventional frequencies and high frequencies in dental practices have shown a tendency toward lower thresholds, suggesting that significant hearing problems accumulate with time. As the frequency, time of exposure, and age increases, there is a greater decay in hearing acuity. These studies also observed a greater incidence of hearing loss in the frequencies of 6,000 $\mathrm{Hz}$ and 14,000 Hz.

LOPES and GODOY (2006) compiled a literature review regarding the importance and contribution of high-frequency audiometry for the early identification of NIHL. They demonstrated that conventional tonal threshold audiometry alone may not be effective in the identification or prevention of NIHL, and also described the methodological variables for its proper execution. The authors also suggested this method should be added to the routine that is indicated by the Occupational Hearing Loss Prevention Program. Therefore, the purpose of this study was to investigate the hearing thresholdsat conventional and high frequencies, thus enabling early prevention of hearing loss and and improving the overall hearing health of the population as a whole.

\section{METHOD}

This study began after the approval of the Ethics Committee of the University of São Paulo under process number $043 / 2007$. This research study was financed by the São Paulo Research Foundation (FAPESP) funding agency under process number 2007/01074-7.

This was a cross-sectional study with 108 volunteer participants the Bauru community, which were divided into 3 experimental groups. The groups were named I, II, and III. Group I (GI) consisted of 44 dentists ( 16 males and 28 females) aged between 23 and 57 years (average of 34 years of age). Group II (GII) consisted of 36 female dental nurses, aged between 21 and 59 years (average of 38 years of age). Lastly, Group III (GIII) consisted of 28 prosthodontists ( 17 males and 11 females) aged between 17 and 53 years (average of 35 years of age).

Professionals from private dentistry offices or laboratories, universities in Bauru, São Paulo, and hospitals that employ dentists on their staff were invited to participate. The participants initially received clarifications regarding the purpose of this study, which only began after the agreement to participate and the signature of the informed consent were obtained.

For the inclusion and exclusion criteria, only professionals in the dentistry field with at least 2 years of experience, who did not present any pre-existing diseases such as mumps, high blood pressure, diabetes, meningitis, human immunodeficiency virus (HIV), syphilis, and other conditions that can compromise hearing and/or pre-existing hearing impairment were considered.

All the participants were underwent:

- A specific interview and middle ear inspection: these procedures were performed to investigate the individual features such as age, time in the profession, noisy entertainment habits, exposure to chemical products, as well as health conditions and other diseases that can aggravate the effect of environmental risks.

- Conventional tonal threshold audiometry (250 to $8,000 \mathrm{~Hz}$ ), high-frequency tonal threshold audiometry (9,000 to $16,000 \mathrm{~Hz})$, and speech reception threshold tests were performed using a Siemens SD 50 audiometer. For the tests of the tonal thresholds the warble tone was used, which was presented using aural headphones (HDA 200). The descendent technique was used for the tests of the tonal thresholds. The hearing threshold was established when there was a $50 \%$ positive answer for sound detection (LOPES and Godoy, 2006).

- Acoustic impedance test: the acoustic immitance measures and the ipsilateral and contralateral acoustic reflex tests of the stapedius muscle were performed with GSI Tymp Star. They were classified as suggested by JERGER (1970). 


\section{RESULTS}

The data analysis from the specificinterview revealed that 65 participants were bothered by noise at work, 50 participants reported difficulties in speech comprehension, 8 had served in the army, 11 had acoustic trauma, 32 were exposed to chemical products, and 35 referred to being exposed to noise during recreational activities.

Graph 1 shows the mean hearing thresholds for all of the frequencies that were tested in the 3 groups.

The comparison between the mean hearing thresholds of each frequency that was tested in the 3 groups was performed using the Kruskall-Wallis test, and considered significant by the Dunn test. We obtained a statistically significant difference in the right ear for the frequencies of $2,000 \mathrm{~Hz}(\mathrm{p}=.0446), 8,000 \mathrm{~Hz}(\mathrm{p}=.0492)$, and $16,000 \mathrm{~Hz}(\mathrm{p}=.0441)$ when the mean of Group I (mean threshold at $2,000 \mathrm{~Hz}=5.91 \mathrm{~dB}$, at $8,000 \mathrm{~Hz}=11.59$ $\mathrm{dB}$, and at $16,000 \mathrm{~Hz}=21.59 \mathrm{~dB}$ ) was compared to the mean of Group II (mean threshold at $2,000 \mathrm{~Hz}=10.69 \mathrm{~dB}$, at $8,000 \mathrm{~Hz}=18.61 \mathrm{~dB}$, and at $16,000 \mathrm{~Hz}=32.78 \mathrm{~dB}$ ); hence, we verified that GII presented worse thresholds at the frequencies of 2,000 Hz, 8,000 Hz, and $16,000 \mathrm{~Hz}$ in the right ear compared to GI.

It can observed that the right and left ears presented similar configurations in conventional and high-frequency audiometry, when the mean hearing thresholds for all of the groups is considered; however, the right ear presented worse hearing thresholds than the left ear.

For the left ear, the frequencies of $4,000 \mathrm{~Hz}(\mathrm{p}=$ $.0238)$ and $6,000 \mathrm{~Hz}(\mathrm{p}=.0310)$ presented statistically significant differences between GI (mean threshold at $4,000 \mathrm{~Hz}=8.41 \mathrm{~dB}$ and at $6,000 \mathrm{~Hz}=14.32 \mathrm{~dB}$ ) and GII (threshold mean at $4,000 \mathrm{~Hz}=14.03 \mathrm{~dB}$ and at $6,000 \mathrm{~Hz}$ $=20.69 \mathrm{~dB}$ ) and between GI and GIII (mean threshold at $4,000 \mathrm{~Hz}=15.36 \mathrm{~dB}$ and at $6,000 \mathrm{~Hz}=22.32 \mathrm{~dB}$ ). At the frequency of $9,000 \mathrm{~Hz}$ in the left ear, there was a statistically significant difference ( $p=.0397$ ) between GI (mean theshold at $9,000 \mathrm{~Hz}=10.91$ ) and GII (mean threshold at $9,000 \mathrm{~Hz}$ $=20.28 \mathrm{~dB}$ ).

The comparison of the mean hearing thresholds at the frequencies of $500 \mathrm{~Hz}$ to $2,000 \mathrm{~Hz}, 3,000 \mathrm{~Hz}$ to $6,000 \mathrm{~Hz}, 9,000 \mathrm{~Hz}$ to $16,000 \mathrm{~Hz}$, and $12,000 \mathrm{~Hz}$ to $16,000 \mathrm{~Hz}$ was performed using the Kruskall-Wallis test, and the statistical significance was determined by the Dunn test. For these comparisons, a statistically significant difference $(\mathrm{p}=.0147)$ was obtained only when the mean thresholds between the frequencies of $3,000 \mathrm{~Hz}$ to $6,000 \mathrm{~Hz}$ in the left ear between GI (10 dB) and GII

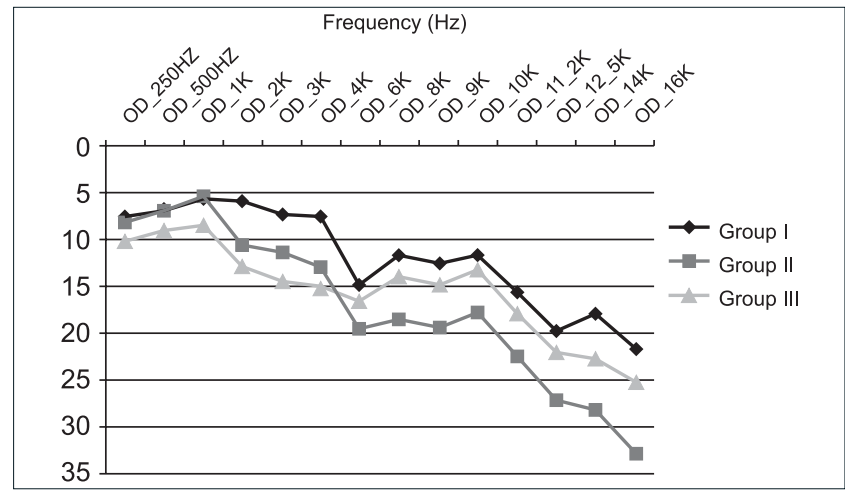

Graph 1. Hearing thresholds of the right ear in all of the tested groups.

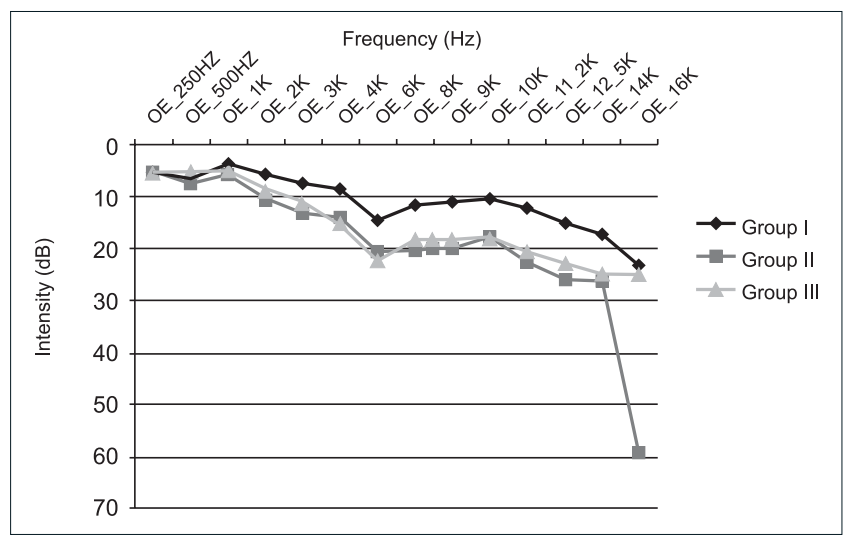

Graph 2. Hearing thresholds of the left ear in all of the tested groups.

(15.93 dB) and those between GI (10 dB) and GIII (16.25 dB) were compared.

The speech audiometry, which was performed using the speech recognition threshold, confirmed the results of the conventional audiometry in $100 \%$ of the participants, as did the speech recognition index, which was compatible with the hearing thresholds found in $100 \%$ of the participants.

For the acoustic immitance and evaluation of the ipsilateral and contralateral stapedius muscle reflexes, normal tympanograms were obtained bilaterally in 100\% of the participants, thus indicating that the middle ear did not interfere with the results that were obtained.

\section{DISCUSSION}

This study focused on a sample of dentists, dental nurses, and Prosthodontists with more than 2 years of 
experience in the dentistry field and with an average age of 35 years among the 3 groups.

In this population, hearing loss can occur due to prolonged exposure to high-frequency sounds that are produced by the instruments that are used in their daily practice, which results in subsequent handicaps to their communication and quality of life (Hinze, Deleon, and Mitchel, 1999).

This study showed that only $60 \%$ of the participants were bothered by noise at work (SOUZA, 1997; TôRREs et al., 2007; Melo et al., 2008), that 43.3\% of the participants reported difficulties in speech comprehension, and that $32.4 \%$ mentioned that they were exposed to noise during recreational activities.

This study revealed that the mean hearing thresholds of all of the groups worsened according to increases in frequency (Matthews et al., 1997; Beltrami, 1999; Fernandes and Mota 2001; Mota , 2002; Porto et al., 2004; Silva and Feitosa, 2006; Lopes et al., 2006; Lopes and Godoy, 2006; Lopes, Almeida, Zanconato, and Mondelli, 2007; Carvalho, Koga, Carvalho, and Ishida, 2007). For all of the groups, both conventional and high-frequency audiometry of each ear showed similar configurations; however, by comparing both ears in the 3 groups, we observed that the right ear showed worse mean thresholds than the left ear. These results are in agreement with ZuBICK, Tolentino, and Boffa (1980), and are in disagreement with GijBels et al. (2006), who gathered data on the effects of occupational health among dentists and observed that hearing loss was greater for the left side for right-handed professionals, which can be explained by the short distance between the left ear and the circular motion/vibration equipment for right-handed professionals.

The tritonal means of 500 to 2,000 Hz and 3,000 to $6,000 \mathrm{~Hz}$ revealed that prosthodontists (GII) had the worst hearing thresholds. For the high-frequency mean $(9,000$ to $16,000 \mathrm{~Hz}$ ) the dental nurses (GII) had the worst hearing thresholds. These results highlight the importance of using complementary tests in the hearing evaluation (which in this case was high-frequency tonal threshold audiometry), and that if these tests are used as a routine procedure in the evaluation of these professionals it would assist in the early detection and prevention of hearing problems.

\section{Conclusion}

In this study, we concluded that the conventional hearing assessment did not identify hearing problems in the 3 groups that were tested. However, the assessments of the high-frequency thresholds indicated disturbances to the peripheral auditory system, specifically on the external hair cells, thereby demonstrating greater sensitivity for the early detection of hearing problems and favoring the use of complementary tests as prevention tools.

\section{BibliograpHIC RefERENCES}

1. Altinoz HC, Gokbudak R, Bayraktar A, Belli SA. A pilot study of measurement of the frequency of sounds emitted by high-speed dental air turbines. J Oral Sci. 2001, 43(3):18992 .

2. American Dental Association. Council on dental research. Sound hazard of high-peed cutting instumensts. Journal of the American Dental Associations. 1959, 58:145.

3. Amorin RB, Lopes AC, Santos KTP, Melo ADP, Lauris JRP. Alterações auditivas da exposição ocupacional em músicos. Arq. Int otorrinolaringol. 2008, 12(3):377-383.

4. Beltrami CHB. Dos limiares de audibilidade nas frequências de 250 a $18.00 \mathrm{~Hz}$ em indivíduos expostos a ruído ocupacional. Tese: Doutorado. Universidade Federal de São Paulo. 1999.

5. Brasil. Ministério do Trabalho-Secretaria da Segurança e Saúde no Trabalho. Portaria no. 19, de 09 de abril de 1998. diretrizes e parâmetros mínimos para a avaliação e acompanhamento da audição em trabalhadores expostos a níveis de pressão sonora elevados. Diário Oficial da União. Brasília, 22 de abril de 1998.

6. Comitê Nacional de Ruido e Conservação Auditiva. Perda auditiva induzida por ruído relacionada a o trabalho. Boletim, São Paulo, noำ 1, 1999.

7. Carvalho RMM, Koga MC, De Carvalho M, Ishida IM. Limiares auditivos para altas frequencias em adultos sem queixa auditiva. ACTA ORL/Técnicas em Otorrinolaringologia. 2007, 25(1):62-6.

8. Fernandes JB, Mota HB. Estudo dos limiares de audibilidade nas altas frequências em trabalhadores expostos a ruído e solvente. Pró-fono. 2001, 13(1):1-8.

9. Fernandes JC, Ovileira JRE, Fernandes VM. Avaliação do ruído em consultório odontológico. XI SIMPEP. Bauru/SP. 2004.

10. Fiorini AC. O uso de registro de emissões otoacústicas como instrumento de vigilância epidemiológica de alterações auditivas em trabalhadores expostos a ruído. [Tese, Doutorado em Saúde Ambiental] Faculdade de Saúde Pública, Universidade de São Paulo, São Paulo, 2000. 
11. Gatto CI, Lermen RA, Teixeira TM, Magni C, Morata TC. A análise da conduta de médicos do trabalho diante de trabalhadores com perda auditiva. Rev Dist Com. 2005 17(1):101-15.

12. Gijbels et al. Potential occupational health problems for dentists in Flanders, Belgium. Clin Oral Invest Flanders. 2006, 10(1):8-16.

13. Hanger MRHC, Barbosa-Branco A. Efeitos auditivos decorrentes da exposição ocupacional ao ruído em trabalhadores de marmorarias no Distrito Federal. Rev Assoc Med Bras. 2004, 50(4):396-9.

14. Hinze H, Deleon C, Mitchel WC. Dentist at High Hisk for Hearing Loss: protection with custom earplugs. General Dentistry. 1999, 47(6):600-603.

15. JergerJ. clinical experience with impedance audiometry. Arch Otolaryngol. Chicago. 1970, 92(4):311-24.

16. Leggat PA, Chwanadisai S, Kukiattrakoon B, Yapong B, Kedjarune U. Occupational health problems of dentists in southern Thailand. Int Dent J Feb. 2000 50(1):36040.

17. Lopes AC, Almeida BK, Zanconato CM, Mondelli MFCG. Estudo dos limiares de audibilidade de altas frequências em crianças ouvintes comidades entre 7 e 13 anos. Dist. Comun. 2007, 19(2):173-180.

18. Lopes AC, Godoy JB. Considerações metodológicas para a investigação dos limiares de frequência ultra-altas em indivíduos expostos ao ruído ocupacional. Salusvita. Bauru. 2006, 25(2):149-160.

19. Luxon LM. The clinical diagnosis of noise induced hearing loss. Advances in Noise Research, Londres, 1998.

20. Matthews LJ, Lee FS, Mills Jh, DubnoJR. Extended highfrequency threshold in older adults. Journal of speech, language, and hearing research. 1997, 40:208-14.

21. Melo et al. Aspectos odontolegais da insalubridade na odontologia. RGO. Porto Alegre. 2008, 56(2):143-9.

22. Mota SSR. Estudo dos limiares auditivos de cirurgiões cirurgiões dentistas nas frequências de 500 a $16.000 \mathrm{~Hz}$. Dissertação de Mestrado em Distúrbios da Comunicação. Curitiba: Universidade Tuiuti do Paraná, 2002.
23. Oliveira et al. Ruído ambiental e sua percepção pelos alunos de odontologia. Revista de Odontologia da UNESP. 2007, 36(1):9-16.

24. Áurea Otoni, Marlene Escher Boger, Anadergh BarbosaBranco, Helena Eri Shimizu, Mariluci Alves Maftum. Ruído ocupacional como fator de risco para perda auditiva. Cogitare Enferm. 2008, 13(3):367-73.

25. PAraguay ATT. Perda Auditiva Induzida por Ruído em Consultório Odontológico. Recife, 1999. Trabalho de conclusão de curso de especialização, CEFAC.

26. Porto MAA, Lopes AC, Gayva D, Lauris JRP . Avaliação da audição em frequências ultra-altas em indivíduos expostos ao ruído ocupacional. Pró-fono, Baueri-SP. 2004, 16(3):237250.

27. Presta AA, Garbin CAS, Garbin AJI, Saliba. Avaliação da Ocorrência de Doenças e Acidentes Ocupacionais entre Acadêmicos de Odontologia. Revista da Faculdade de Odontologia de Passo Fundo. 2004, 9(1):113-117.

28. Rabinowitz PM. Noise induced hearing loss. Am Fam Physician, Kansas City. 2000, 61(9):2749-56/2759-60.

29. Segurança e Medicina do Trabalho. Atlas S.A. 1991, 20 ed.; 16:95-6.

30. Sava LC, protocolo de avaliação para populações expostas a ruído indistrial. In: Morata TC, Zucki F. (Orgs). Caminhos para a saúde auditiva ambiental-ocupacional. São Paulo: Plexus. 2005, 189-202.

31. Silva IMC, Feitosa MAG. Audiometria de alta frequência em adultos jovens e mais velhos quando a audiometria convencional é normal. Rev. Bras. Otorrinolaringol. São Paulo. 72(5), Sept./Oct., 2006.

32. Souza HMMR. Ruído, o inimigo invisível: visão do cirurgião dentista. RBO, 54(2):97-101, 1997.

33. Tôrres BO, et al. A Perda Auditiva Induzida pelo Ruído (PAIR) na formação acadêmica: conhecimentos e medidas de prevenção - Odontologia. Clín. Científ., Recife. 2007, 6(2):151-154.

34. Zubick HH, Tolentino AT, Boffa J. Hearing loss and the high spped dental handpiece. Am J Public Health. 1980, 70(6):633-5. 